\title{
The Influencing factors and Countermeasures of College Students' Innovation and Entrepreneurship Ability from the Perspective of College Students and Teachers
}

\author{
Zhenbo Bao ${ }^{1, a^{*}}$, Hongjun Teng1, b , Jinxing Peng ${ }^{1, c}$, \\ Dengchao Jin ${ }^{1, d}$ and Xinyuan Liu ${ }^{1, e}$ \\ ${ }^{1}$ Engineering and Technology College, Tianjin Agricultural University, Tianjin, China, 300384 \\ a*zhenbobao@sohu.com, bhongjun-teng@163.com, ${ }^{*}$ pengjinxing@163.com, \\ djindengchao@163.com, diuxinyuan@tjau.edu.cn
}

Keywords: Innovation and entrepreneurship; Influence factors; College students; Improve countermeasures

\begin{abstract}
As a base for cultivating innovative entrepreneurship talents, colleges play an important role in cultivating innovative entrepreneurship talents. The ability of college students' innovation and entrepreneurship can be assessed through innovation and entrepreneurship theory, innovation thinking, entrepreneurial initiative, and innovation and entrepreneurship ability, which are closely related to college students themselves and teachers. From the perspective of college students, on the basis of summarizing the influencing factors of college students' innovation and entrepreneurship ability, the measures to improve the ability of college students' innovation and entrepreneurship are summarized. From the perspective of college teachers, on the basis of summarizing the influencing factors of college students' innovation and entrepreneurship ability, the measures to improve the ability of college students' innovation and entrepreneurship are summarized. From the point of view of college students and teachers, the factors influencing the innovation ability of college students are analyzed and some improvement measures are put forward, which has important practical significance for improving the quality of innovative talents training.
\end{abstract}

\section{Introduction}

To develop college students' innovation and entrepreneurship education is the effective path to realize college students' own development, is the important measures to alleviate the employment pressure, at the same time also is the inevitable requirement of development strategy of China's innovation drive. As a base for cultivating innovative entrepreneurship talents, colleges play an important role in cultivating innovative entrepreneurship talents. Colleges should make the cultivating of college students' innovation and entrepreneurship ability as an important task. The ability of innovation and entrepreneurship can be assessed through innovation and entrepreneurship theory, innovation thinking, entrepreneurial initiative, and innovation and entrepreneurship ability, which are closely related to college students themselves and teachers. From the point of view of the college students and teachers, the factors influencing the innovation ability of college students are analyzed and some improvement measures are put forward[1-2].

The Factors Influencing College Students' Innovative and Enterprising Ability from the Perspective of College Students

There are some misunderstandings in college students' entrepreneurial awareness, and their entrepreneurial mentality needs to be adjusted. Some college students do not establish the correct entrepreneurship awareness, some college students believe that entrepreneurship education is a kind of interest activity carried out by the school; some college students think that innovation is only to get enough income; some college students choose to start their own business because of the existing 
employment pressure, lack the necessary psychological ability and good crisis processing capacity. In this way, the participation of college students in innovation and entrepreneurship is not high [3-5].

College students lack of innovation and entrepreneurial knowledge. Entrepreneurship knowledge includes professional knowledge, management knowledge and comprehensive knowledge. System mastering the basic theoretical knowledge of entrepreneurship can lay a solid foundation for entrepreneurship. Now the lack of integration of innovation and entrepreneurship knowledge, such as registration, management, marketing, financing and much other comprehensive knowledge, leading to some college students' innovation and entrepreneurship process easily halfway [1, 4-6].

The innovation and entrepreneurial consciousness of college students need to be strengthened. College students' innovation and entrepreneurship awareness are relatively weak, students' critical thinking, observation and insight, decision-making and so on to be strengthened. Some college students in the self-confidence, dedication, social responsibility and pressure ability are not strong enough, affecting the cultivation of college student's innovation and entrepreneurship [1, 4-5].

College students' teamwork ability needs to be improved. A successful innovation and entrepreneurship project is the result of collective cooperation and joint efforts of innovation and entrepreneurship team. At present, college students' teamwork ability and interpersonal ability need to be improved, some college students show lack of initiative, lack of communication, lack of understanding and respect in teamwork, and poor ability to share and cooperate with others. In this way, the improvement of the overall efficiency of the team has been weakened, and the improvement of innovation and entrepreneurship ability of college students has been restricted.

College students own quality and comprehensive ability to be improved. The quality of college students' own qualities such as suntech, professionalism, rigor, patience, concentration, diligence, perseverance, tenacity, and so on are all essential elements of professional quality and psychological quality. However, some college students' sense of social responsibility are weak, the lack of rigorous and serious attitude in study and work, not strict requirements on their own, the lack of tenacity and perseverance, no innovation ability, and mental capacity are weak [6-7].

College students lack of entrepreneurial funds. The entrepreneurial college students need a solid material foundation as a support, college students' venture capital mainly comes from the family. The schools and related departments have relatively less financial support to the entrepreneurial students, and home can be used for the venture capital is getting smaller and smaller. In particular, some students from rural areas still worried about food and clothing can not rely on the family to raise venture capital $[3,8]$.

The improving measures of college students' innovative and enterprising ability from the perspective of college students' self

\section{Strengthen the cultivation of innovation and entrepreneurship awareness for college students.}

To strengthen the cultivation of innovation and entrepreneurship awareness of college students, let college students realize that innovation and entrepreneurship bring not only wealth, but also a social responsibility. Cultivate college students' self-evaluation of learning ability, entrepreneurial inspiration and entrepreneurial ability, and guide students to apply what they have learned to innovation and entrepreneurship practice $[1,5]$.

Focus on improving the quality of college students' innovation and entrepreneurship. Set up correct innovation idea, do poineering work plan before starting a business. Set up firm belief and be ready for hard work. Set up the correct risk consciousness of innovation and entrepreneurship, and carry out innovation and entrepreneurship according to actual situation [4-6].

Construct reasonable structure of innovation and entrepreneurial knowledge. College students to take advantage of rich resources of school, through classroom learning, using library resources and network resources, not only should pay attention to the basic knowledge of learning, but also strengthen innovative entrepreneurial learning professional knowledge. In addition, through innovation and entrepreneurship activities, innovation and entrepreneurship competition, and the exchange of 
successful people in the business community, to broaden the horizon of college students and improve the knowledge structure of innovation and entrepreneurship [4,9].

Actively participate in various innovation and entrepreneurship competitions and scientific research activities. College students should actively participate in the practice of innovation activities inside and outside the school. In the innovative business activities, can better understand and use professional knowledge, train student's awareness of innovation and entrepreneurship, and improve the observation, thinking, imagination and hands-on ability [5-7].

Actively participate in social practice. Social practice is an important way for college students to improve their entrepreneurial consciousness, entrepreneurship and psychological quality. Social practice can promote the organic combination of theory and practice, in the course of practice, college students will encounter new problems that are unanticipated, by solving new problems, can cultivate students' abilities of organizational management, social skills and creativity.

\section{The influencing factors of college students 'innovative and enterprising ability from the perspective of college teachers}

College teachers lack innovative ideas and thinking, and the teaching method is single. In the teaching method, teachers are the center, the teaching material is the center, and the classroom is the center teaching. Students accept knowledge passively instead of actively exploring knowledge, so that students' creative potential is suppressed.

Teaching evaluation and curriculum assessment fail to reflect the cultivation of innovation ability. In teaching evaluation system, the purpose of evaluation is not very clear. The purpose of examination is to consolidate knowledge, test teaching effect, evaluate learning situation, but ignore students' autonomous learning and innovative learning ability. The examination method is single, mainly closed volume, and lack of diversity and openness. The examination method does not form a complete evaluation system, and the evaluation content fails to reflect the requirements of cultivating innovation and entrepreneurial talents. Most of the teaching results are measured by the test, while the exams mostly stay in the study of the students' knowledge, lack of comprehensive, research-oriented and innovative content $[2,7]$.

College teachers ignore the cultivation of innovation consciousness of college students. Under the influence of traditional thinking, some college students hope to find a job that meets their expectations in all respects after graduation, and generally lack independent entrepreneurial consciousness. The teachers themselves are influenced by teaching tasks and research tasks, and have no more energy to invest in the cultivation of innovation consciousness of college students [7-8].

College teachers lack the actual background of engineering, and can't provide effective innovation and entrepreneurship guidance to students. Teachers need to have a deep understanding and practical experience of innovation and entrepreneurship, so as to better guide students. Many college teachers generally have higher education and scientific research ability, but no enterprise engineering background, the lack of practical experience of innovative undertaking, the lack of practical experience, and combined with the teaching and scientific research tasks, can not effectively guide the student to carry on the innovation education practice[3,8].

\section{The improving measures of college students 'innovative and enterprising ability from the perspective of teachers}

Teachers improve teaching methods. College teachers should carry out education and influence on students' innovation and entrepreneurship through daily teaching activities. Teachers to improve teaching method, take the inquiry, discussion, interactive and other modern teaching methods. Teachers to respect the principal position of students and individual differences, follow the rules of student growth, guide students to think independently, independent exploration, and stimulate students' interest in learning. Teachers should formulate rational innovation and entrepreneurship training programs, 
actively organize students to carry out experiments and social practice activities, and cultivate innovative awareness, innovative spirit and entrepreneurial skills [2,4].

Teachers improve the evaluation method of curriculum. In the course of curriculum teaching evaluation, the content of curriculum evaluation should be comprehensive and innovative. The purpose of evaluation should be clear, and the evaluation content should reflect the requirements of cultivating innovation and entrepreneurial talents. Exam should take the form of open-book examination, reflecting the diversity and openness. Assessment should focus on evaluation of students self-learning, innovative learning and practical learning ability.

Teachers strengthen the cultivation of innovation consciousness of college students. Teachers should strengthen the cultivation of innovation and entrepreneurial consciousness of college students, transform the traditional education concept, and change from the emphasis on knowledge transmission to innovation awareness and entrepreneurship ability. To guide college students to practice actively, not afraid of setbacks and to go forward. To guide students to see the value of entrepreneurship, let college students realize that entrepreneurship brings more than money and wealth, while entrepreneurship is also an important means of social responsibility $[2,9]$.

Teachers actively devote themselves to guiding the innovation and entrepreneurship practice of college students. As an important guide for college students to cultivate innovative and entrepreneurial talents, teachers should actively devote themselves to research and practice activities. Teachers accumulate technical experience in engineering practice, and improve their ability of management practice and innovation and entrepreneurship. Teachers should take an active part in guiding college students to carry out innovative and entrepreneurial activities, and give good guidance and cultivation in innovative spirit and entrepreneurial ability $[2,8]$.

\section{Summary}

Launching innovation and entrepreneurship education in colleges is a strategic move to accelerate the transformation of economic development mode and build an innovative country. College students are the main force to implement the strategy of innovation driven development, and the important force to promote the masses' entrepreneurship and innovation. From the perspective of the college students themselves and teachers, the influence factors of college students' innovative ability are analyzed and the improvement measures are put forward, which have important practical significance for improvement the innovation talent training quality $[1,9]$.

\section{Acknowledgements}

This work was sponsored by Tianjin Agricultural University Teachers Education Reform and Innovation to Guide the Development of the Project No. 20170904 and Tianjin Agricultural University Education and Teaching Reform Project No. 2016-B-17.

\section{References}

[1] Y. Tang: Journal of Changchun Education Institute, Vol. 31 (2015) No.9, p.37-38.

[2] L. Han: Chtnese Untverstty Technology Transfer, (2017) No.1, P.121-123.

[3] H. Lan: China Adult Education, (2016) No.15, P.80-81.

[4] G.H. Huang: Theory And Practice Of Education, Vol. 32 (2012) No.36, P.12-14.

[5] X.W. Li: Journal Of Longyan University, Vol. 34 (2016) No.1, P.84-87.

[6] K.L. Zhang: Theory And Practice Of Education, Vol. 31 (2017) No.12, P.21-23.

[7] G.P. Xiao: Chinese University Science \& Technology, (2017) No.7, P.84-87.

[8] G.H. Huang: Journal Of Minnan Normal University, Vol. 30 (2016) No.3, P.150

[9] -152.

[10] Y.M. Kan: Journal Of Jilin Teachers Institute Of Engineering And Technology, Vol.30 (2014) No.12, P.30-31. 